will depend to some extent on the pattern which is eventually recommended by the working party of the schools and the universities. If the outcome is a pattern along the lines which many university educationists have been advocating, A-level subjects as such may eventually disappear from the schools. Everybody seems to agree, however, that that will take a considerable time.

\section{How Engineers Do}

THE College of Engineering at Illinois University has compiled a revealing report on the subsequent progress of its alumni. In financial terms it appears that the brightest graduates do not invariably make out best, but it helps, none the less, to have the letters PhD after one's name.

By 1967 the average monthly salary of those who graduated in 1957 was $\$ 1,227$; holders of a doctorate earned an average of $\$ 1,444$ a month, but those with no advanced degree and those with a master's degree in business administration were alike in bringing home a monthly $\$ 1,196$. Ranking the 370 graduates who answered the questionnaire in ten groups by order of their class of degree, it emerges that the second decile is earning the highest monthly salary $(\$ 1,347)$ and the sixth decile the lowest $(\$ 1,125)$; the correlation between worldly and academic success is present but not conspicuous.

A quarter of the graduates are employed in management or administration; research, development, production and manufacturing account for another quarter. Only 2 per cent are in teaching and one individual has become a psychiatrist. Only 40 per cent had remained in the same job since graduating and more than half of those who changed jobs had done so more than once.

A companion survey made of engineers who graduated in 1962 produced similar results. With an average monthly salary of $\$ 968$, only 10 per cent of the younger alumni were in management and proportionately more in research and development. To the question of whether any persons known to them had left jobs in industry because of the "unfavourable attitude of young people toward business and their dissatisfaction and disillusionment with American industry", a third of both groups replied in the affirmative. Between a quarter and a third read the Wall Street Journal, but less than 4 per cent admit to taking the New Yorker.

\section{New Booster}

THE Goldfinch booster is half way through its flight trials at Woomera and could come into service in 18 months. It will provide a most useful addition to the capacity and versatility of the Skylark sounding rocket, the principal tool of the British space research programme for the past 10 years

There is already one booster available for improving Skylark's performance, called Cuckoo. With the advent of the highly successful stabilized Skylark which enabled a start to be made on X-ray astronomy and has already made important contributions to solar physics, payload demands on Skylark have increased. The stabilization equipment in the nose cone accounts for a sizable proportion of the payload, reducing the weight available for experiments. A
Cuckoo-boosted Skylark is used for stabilized flights. The Goldfinch booster's performance is about double that of Cuckoo; it will add about 6 feet to the total vehicle length. The object is to carry a 600 -pound payload to $200 \mathrm{~km}$ or so. In terms of the same payload weight, this is $30-40 \mathrm{~km}$ higher than is possible with the Cuckoo-boosted Skylark. This will add a few seconds of experimental time. Alternatively a smaller payload could be carried to greater altitude or a larger one to a lesser height. Individual flight configurations are tailored to the requirements of the particular experiment. The addition of the Goldfinch facility will therefore further stretch the basic Skylark vehicle and increase its value for scientific work.

The 14 Skylark flights from Woomera last year were all successful, and the rocket has proved a very reliable performer. It and its boosters all employ plasticized solid propellant developed at the Government's Explosives Research and Development Establishment at Waltham Abbey. The current proving tests of the Goldfinch booster at Woomera are in the hands of the Royal Aircraft Establishment, and when they are complete the British Aircraft Corporation at Bristol will take over production. The Science Research Council is the commissioning authority.

\section{New Computer Man}

International Computers, Limited, at last has a permanent chairman. ICL, formed by the merger of International Computers and Tabulators with the computer interests of English Electric and Plessey, has been looking for a chairman for some months. Last week it announced that the man is to be Sir John Wall, whose career includes periods in private industry and in the civil service. Colonel Terence Maxwell, who has been acting as chairman of ICL in a caretaker capacity and who made it clear that he was staying only until a successor could be found, moves down to deputy chairman.

Sir John Wall began his career as a merchant banker but moved into the civil service in 1939 , remaining at the Ministry of Food for thirteen years. In 1952 he transferred to Unilever, and later became managing director of Electrical and Musical Industries, Ltd. Two years ago he was seconded to the General Post Office as a deputy chairman, and has been involved in the operation of changing the Post Office from a government department to a public corporation. $\mathrm{He}$ will not now be returning to EMI at theend of his secondment, but will instead be going to ICL. His appointment seems an admirable one; although not born and bred into computers, Sir John is clearly an able manager with enormous expcrience. ICL, which seems likely to occupy a position somewhere between public and private industry, might have been designed to take advantage of his experience. He is unlikely to be impressed (or depressed) by the complexities of running a business in harness with Whitehall - as well as being a former civil servant himself, he was a member of the Fulton Commission.

\section{Fishing Goes Flat}

The British trawling fleet has had a disastrous year, according to the report of the White Fish Authority for the year ended March 31 . It was even worse than 
the previous year, which was bad enough. The worst news was the loss within twelve days of the three distant water trawlers from Hull early in 1968. The losses of the trawlers highlighted the plight of the distant water fishing fleets. Yields and catches were on the whole good, but average values fell sharply particularly for wet fish from distant waters, and gross returns were reduced below already depressed levels.

One of the industry's troubles seems to be imports. There are no quantitative restrictions on imports of fish into Britain. This in itself may not necessarily lead to an increase in the volume of imports, but they may well unsettle the market. Fish is now a much more easily tradable commodity, thanks to the freezing facilities both on shore and at sea. Increased inshore landings of high quality fish have also had their effect on the markets for deep sea fish. The authority admits, however, that the market for distant water fish would not have been so vulnerable if the quality of the fish were better. The report states the obvious when it says that if trends are to be reversed, it is essential to land fish in fresher condition. The authority thinks that the best hope of doing this lies in boxing the catch at sea, with a view to shortening voyages drastically by fleeting operations. Some of the technical problems involved in such operations are being studied by the authority's research and development programme.

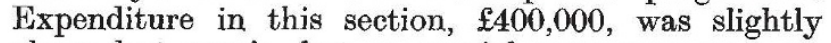
above last year's, but as special arrangements were made with regard to the costs of the exploratory voyage by a freezer trawler to the South Atlantic, expenditure in other parts of the programme actually fell. The programme covers all aspects of the fish industry from catching to marketing, and it includes research into the possibilities of marine fish farming. At the Port Erin hatchery in 1967 , the production target of some 55,000 plaice and 58,000 sole was achieved with good survival rates. At the loch enclosure at Ardtoe, the baby plaice introduced in 1965 reached a mean length of $24 \cdot 6 \mathrm{~cm}$ in 2.5 years; and the sole introduced to the warm water discharge at Hunterston power station in 1966 reached minimum market size in 18 months, about half the time it normally takes.

The main effort at the moment in the research and development programme, however, is in the development of fishing vessels and their equipment. To carry out this part of the programme the authority set up an industrial development unit. The year's work of this body in the fields of mechanization and manpower at sea, increasing productivity, cost effectiveness of vessels and machinery, and quality, variety and acceptability of the fish is outlined in the report. The authority wishes that it had more money to enlarge the programme. The year under review was the third successive year that it had a deficit. "It has become obvious that additional revenue must be made available to the authority if its services are not to be cut."

\section{Infant Science}

"Oceanography is still in its earliest stages; to expect immediate returns is to expect Johnny to run before he can walk." This statement was made by the minister responsible for most of the oceanographic research being done today in Britain, Mrs Shirley Williams, Secretary of State for Education and Science, during a visit to the National Institute of Oceanography last Monday. She added that Britain must have more fundamental research in this field without expecting immediate practical applications and that the Government planned to greatly increase the funds available.

The institute was set up in 1949 primarily because of naval interest in wave research. This was the beginning of oceanographic research in this country; there are now 189 people working at this institute alone. In 1965 the responsibility for the institute was shifted from the National Oceanographic Council to the Natural Environment Research Council.

A new collecting net that can be opened and closed using an acoustic control was demonstrated to the minister. The net is opened when an acoustic signal triggers the release of a bolt, thereby enabling scientists to collect samples from only one depth. Most of the biological work of the institute is concerned with the ecology of marine animals, though work is also being carried out on aspects of animal migration, especially in the vertical plane.

The evidence for continental drift in the eastern North Atlantic is now quite well established, but problems still remain. One interesting theory is that the Bay of Biscay resulted from the anticlockwise rotation of Spain. These and similar theories are being investigated in conjunction with university departments.

\section{Defence Research}

INDUSTRY should play a much greater part in the planning and running of defence research. This recipe for success was presented to the Select Committee on Science and Technology by the body most likely to benefit from its adoption, the Confedoration of British Industry. The witnesses from the CBI, headed by Sir Denning Pearson, the new chairman of Rolls-Royce, suggested that research was carried on in government establishments under "grossly exaggerated security conditions". Later, though, Sir Denning seemed to turn the argument on its head by criticizing the way in which the work on carbon fibre reinforced plastics at Farnborough had been published rapidly (in Nature). "Early publication undoubtedly alerted the world," he declared, but suggested that the damage was done not so much by the content of the paper as by the evidence it gave that Farnborough was hard at work on the new material.

The present system of doing defence research, Sir Denning said, was complicated, and led to delays. In a blessedly short memorandum, the CBI picked out the "interwoven committee structure" of the Ministry of Defence for particular criticism. Projects should be managed by a single man, with full financial responsibility, though the CBI recognized that this might be difficult to organize in the Civil Service. Sir Denning thought that the difficulties of recruiting talented project managers had been exaggerated-Rolls-Royce, he said, always managed to find them. He went on to suggest that, in Britain, an industry's ability to compete internationally could be graded on the basis of the ratio of research work in the industry to that in government establishments. Too often, he said, cuts in the strength of the armed services had not been matched by similar cuts in the establishments. "There must be room for substantial cuts," he said. But establishments had a life of their own, and were very difficult to reduce 